\title{
Current Trends in Architectural Engineering Education
}

\section{Prof. John J. Phillips, Oklahoma State University}

JOHN PHILLIPS, a registered engineer and associate professor of architectural engineering, practiced as a structural engineer for nine years before returning to his alma mater to teach at Oklahoma State University. He teaches undergraduate and graduate courses including Statics, Analysis I, Foundations, Timbers, Steel, Concrete, Steel II, Concrete II, Steel III, Concrete III, and in the Comprehensive Design Studio. 


\title{
Current trends in Architectural Engineering Education
}

\begin{abstract}
With the recent addition of a newly accredited program there are now 21 ABET accredited Architectural Engineering (AE) programs in the United States. There exists a variety of offerings within the programs, and it would be to the advantage of those involved in educating Architectural Engineering students to better understand the similarities and differences of these programs. With the variety of focuses in Architectural Engineering programs there are going to be differences that if understood could lead to better collaboration between universities, taking advantage of the strengths of the individual programs.

The results of a study were published over 10 years ago on the then current Architectural Engineering programs in the United States and included a comparison of the programs. Since that time there have been new programs accredited and several of the programs have gone through major changes to their curriculum. With changes to the number and focus of the programs it is time to perform an updated study. This paper will include a look into the logistics of current ABET accredited Architectural Engineering programs with comparisons of the programs.
\end{abstract}

\section{Introduction}

The Architectural Engineering profession has been in existence for over 100 years with current programs being accredited by the Accreditation Board for Engineering and Technology, or ABET. There are four areas of focus required in ABET accredited Architectural Engineering programs: building structures, building mechanical systems, building electrical systems, and construction/construction management. Individual programs are allowed to determine which of these areas of focus are at the center of their curriculums however each of the four must be addressed in some manner. Currently there are 21 ABET accredited Architectural Engineering programs in the United States and this number has increased to include four new programs over the past 10 years. The four programs in Architectural Engineering that have become accredited over the past ten years include Texas A \& M Kingsville, Worcester Polytechnic Institute, University of Detroit Mercy, and Lawrence Technological University. With such a small number of accredited programs in existence it could be advantageous to know more about each program and have a database of information that could be accessed by the public to better understand Architectural Engineering education.

A major struggle for some AE programs is that much of the public is unaware of what we do. In part the field of Architectural Engineering has an identity issue stemming from the terms architecture and engineer being in the title. The public is often confused on what an AE does with many thinking we are architects while others thinking that our graduates cannot become registered as professional engineers. AE programs are also in constant competition with and greatly outnumbered by Civil Engineering programs. Currently there are 21 ABET accredited Architectural Engineering programs in the United States, and 247 ABET Civil Engineering programs [1]. This big discrepancy between numbers of programs translates into graduation rates as well. In 2016, the number of Civil Engineering Bachelor degrees awarded was 11,464 
while the Architectural Engineering degrees awarded was 618, according to ASEE, a ratio of over 18:1 [2]. Over the past decade, growth in the number of bachelor degrees awarded has occurred in the field of Civil Engineering while it has decreased in the field of architectural engineering. In 2005 there were 8247 bachelor degrees awarded in civil engineering and 722 awarded in architectural engineering [3]. Thus in the past decade civil engineering degrees has increased by $39.0 \%$ while architectural engineering degrees have decreased by $14.4 \%$. The small number of AE programs means each must do a better job of promoting themselves and how graduates of their programs can be leaders in the profession, as well as promoting the profession itself. An updated study of the various programs would enable those interested to better understand what is available in higher education, helping individuals to pursue their interest in becoming an Architectural Engineer.

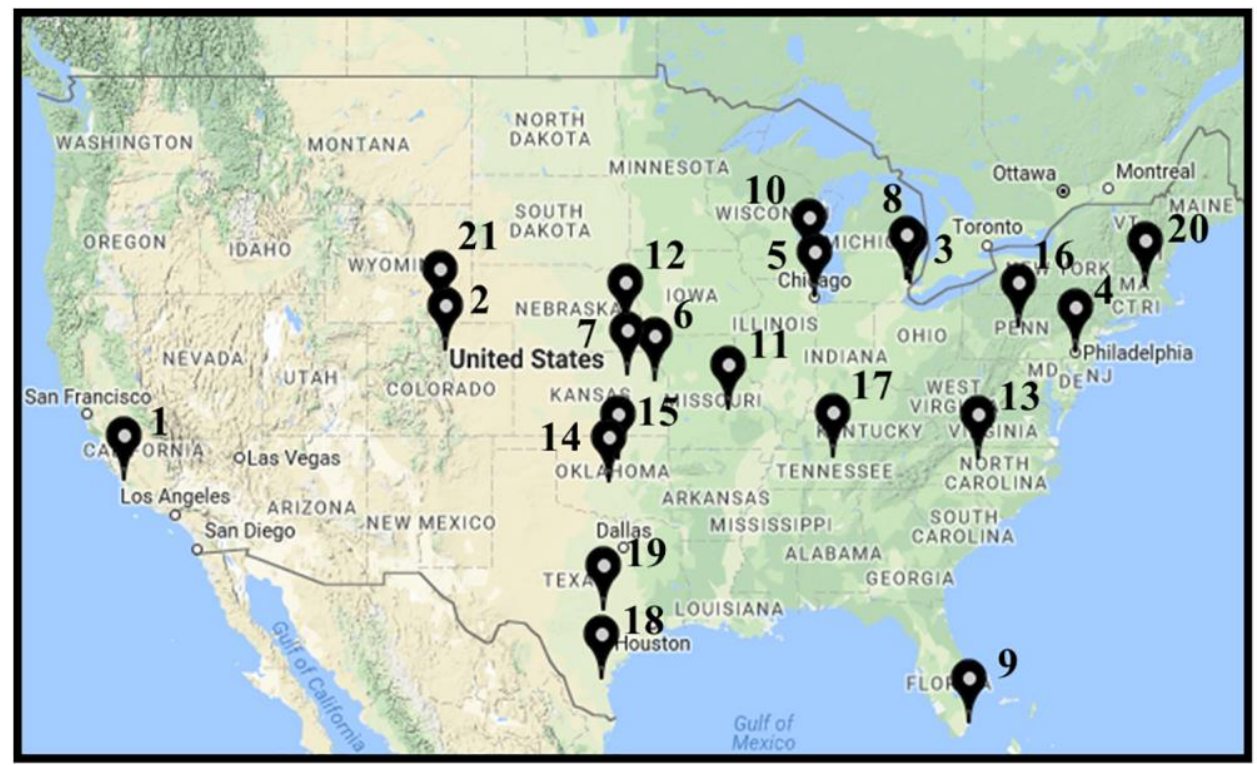

Accredited AE Programs

1) Cal Poly

2) Colorado

3) Detroit Mercy

4) Drexel

5) IIT

6) Kansas

7) Kansas State

8) Lawrence Tech

9) Miami

10) Milwaukee

11) Missouri $S \& T$

12) Nebraska- Lincoln

13) NC A\&T

14) Oklahoma

15) Oklahoma State

16) Penn State

17) Tennessee State

18) Texas A\&M Kingsville

19) Texas

20) WPI

21) Wyoming

Fig. 1: Locations of ABET accredited AE programs in the U.S.

A literature search of studies performed on the logistics of Architectural Engineering programs yielded that there has been limited research performed on the topic. A study published in 2007 was found that included focus on individual program logistics for the then current ABET accredited AE programs in the United States [3]. When this initial study was published on the state of Architectural Engineering programs there were 17 ABET accredited programs in the United States, and currently that number stands at 21. Another study that centered on the faculty at each AE program was published in 2009 , and though it does not correlate directly to the focus of this paper, it does give an overview of faculty logistics for each program [4]. A third study published by this author is included in the references for its information that formed the basis of this study. The focus of that publication was the development of new degree options for an AE program, and included research into the then current ABET accredited programs to determine what other AE programs offered in terms of degree options [5]. At the time of that study there were 20 accredited AE programs in the United States. 


\section{ABET Requirements for Accreditation as an AE Program}

The Accreditation Board for Engineering and Technology, or ABET, accredits programs at the associate, bachelor, and master degree levels in disciplines that include engineering, engineering technology, computing, and applied science at the college and university level. For the 24 ABET accredited Architectural Engineering programs worldwide, it is ABET that evaluates programs to determine if they meet the standards to be accredited by their agency. In addition to $\mathrm{AE}$ programs, ABET is responsible for the accreditation of over 3,500 other programs at 700+ universities and colleges from 29 countries.

Requirements of ABET accreditation must be met by each program, demonstrating that its graduates can apply several topics, including math, chemistry, and calculus based physics. For Architectural Engineering programs additionally, these requirements include four basic curriculum areas - building electrical systems, building mechanical systems, building structures, and construction/construction management. As a minimum, graduates are expected to have design (synthesis) knowledge in one of these areas, an application of knowledge in another area, and comprehension in the remaining two areas. Design knowledge is to be taught considering processes and systems from multiple AE curriculum courses, working well with architectural design, and including communication and collaboration in a team setting. Additionally it is to consider standards and codes, integrate computer technology, and to consider building performance and sustainability fundamentals. In individual programs this design knowledge is often referred to as a focus, and in some of the programs this focus in delivered as a degree option(s) within the program. Having a degree option in an AE program is not a requirements of ABET, and the majority of programs currently do not offer degree options in their curriculum. For some programs there is not a stated focus or degree option even though one can be seen upon examination of the program's curriculum requirements.

\section{An overview of ABET accredited AE programs}

Architectural Engineering programs are located across the United States as shown in Figure 1, with three located in the Northeast region, eight in the Midwest region, seven in the South region, and three in the West region. The largest concentration of programs occurs in the central United States along or near the I-35 corridor. Programs in this part of the country include two programs each in states of Texas, Oklahoma, and Kansas, and a program in Nebraska. Other programs within driving distance include those in Colorado, Missouri, and Wyoming. Towards the east coast there are scattered programs within close proximity to each other. Only two programs (Cal Poly and Miami) are geographically isolated from the other AE programs, being located on the west coast and the extreme southeast coast respectively. In considering the geographical location of these programs, one can see the potential for interaction and collaboration between many of the schools.

When comparing the aspects of each of the ABET accredited programs, several logistics were examined. The first centered on the number of hours needed to graduate from each program. Table 1 shows each of the accredited programs, the department where the program is housed at each university, number of years in the program's curriculum, and credit hours required for graduation. Three of the programs are established on the quarter system with the equivalent 


\begin{tabular}{|c|c|c|c|c|}
\hline $\begin{array}{c}\text { ABET Accredited } \\
\text { Architectural Engineering } \\
\text { Program Information }\end{array}$ & $\begin{array}{c}\text { College / } \\
\text { Department / } \\
\text { School }\end{array}$ & $\begin{array}{l}\text { Program } \\
\text { Length } \\
\text { (Years) }\end{array}$ & $\begin{array}{l}\text { Credit } \\
\text { Hours }\end{array}$ & $\begin{array}{l}\text { Semester / } \\
\text { Quarter }\end{array}$ \\
\hline $\begin{array}{l}\text { California Polytechnic State University }{ }^{[6]} \\
\text { San Luis Obispo, CA }\end{array}$ & $\begin{array}{l}\text { College of Architecture and } \\
\text { Environmental Design }\end{array}$ & 4 & $196(131)$ & Quarter \\
\hline $\begin{array}{l}\text { University of Colorado at Boulder }{ }^{[7]} \\
\text { Boulder, CO }\end{array}$ & College of Engineering & 4 & 128 & Semester \\
\hline $\begin{array}{l}\text { University of Detroit Mercy }{ }^{[8]} \\
\text { Detroit, MI }\end{array}$ & $\begin{array}{l}\text { College of Engineering and } \\
\text { Science }\end{array}$ & 5 & 170 & Semester \\
\hline $\begin{array}{l}\text { Drexel University } \\
\text { Philadelphia, PA }\end{array}$ & College of Engineering & 4 & $193(129)$ & Quarter \\
\hline $\begin{array}{l}\text { Illinois Institute of Technology }{ }^{[10]} \\
\text { Chicago, IL }\end{array}$ & College of Engineering & 4 & 131 & Semester \\
\hline $\begin{array}{l}\text { University of Kansas }{ }^{[11]} \\
\text { Lawrence, KS }\end{array}$ & School of Engineering & 4 & 132 & Semester \\
\hline $\begin{array}{l}\text { Kansas State University }{ }^{[12]} \\
\text { Manhattan, KS }\end{array}$ & College of Engineering & 4 & 128 & Semester \\
\hline $\begin{array}{l}\text { Lawrence Technological University }{ }^{[13]} \\
\text { Southfield, MI }\end{array}$ & College of Engineering & $5 *$ & 164 & Semester \\
\hline $\begin{array}{l}\text { University of Miami }^{[14]} \\
\text { Coral Gables, FL }\end{array}$ & College of Engineering & 4 & 127 & Semester \\
\hline $\begin{array}{l}\text { Milwaukee School of Engineering }{ }^{[15]} \\
\text { Milwaukee, WI }\end{array}$ & $\begin{array}{l}\text { Department of Civil and } \\
\text { Architectural Engineering and } \\
\text { Construction Management }\end{array}$ & 4 & $191(127)$ & Quarter \\
\hline $\begin{array}{l}\text { Missouri University of Science and Technology }{ }^{[16]} \\
\text { Rolla, MO }\end{array}$ & $\begin{array}{l}\text { College of Engineering and } \\
\text { Computing }\end{array}$ & 4 & 128 & Semester \\
\hline $\begin{array}{l}\text { University of Nebraska - } \text { Lincoln }^{[17]} \\
\text { Lincoln, NE }\end{array}$ & College of Engineering & $5 *$ & 165 & Semester \\
\hline $\begin{array}{l}\text { North Carolina A\&T State University }{ }^{[18]} \\
\text { Greensboro, NC }\end{array}$ & College of Engineering & 4 & 128 & Semester \\
\hline $\begin{array}{l}\text { University of Oklahoma }^{[19]} \\
\text { Norman, OK }\end{array}$ & College of Engineering & 4 & 130 & Semester \\
\hline $\begin{array}{l}\text { Oklahoma State University }{ }^{[20]} \\
\text { Stillwater, OK }\end{array}$ & $\begin{array}{c}\text { College of Engineering, } \\
\text { Architecture, and Technology }\end{array}$ & 5 & 157 & Semester \\
\hline $\begin{array}{l}\text { Pennsylvania State University } \\
\text { University Park, PA }\end{array}$ & College of Engineering & 5 & 160 & Semester \\
\hline $\begin{array}{l}\text { Tennessee State University }{ }^{[22]} \\
\text { Nashville, TN }\end{array}$ & College of Engineering & 4 & 128 & Semester \\
\hline $\begin{array}{l}\text { Texas A\&M University - Kingsville }{ }^{[23]} \\
\text { Kingsville, TX }\end{array}$ & College of Engineering & 4 & 128 & Semester \\
\hline $\begin{array}{l}\text { University of Texas at Austin }{ }^{[24]} \\
\text { Austin, TX }\end{array}$ & $\begin{array}{c}\text { Department of Civil, } \\
\text { Architectural and } \\
\text { Environmental Engineering }\end{array}$ & 4 & 126 & Semester \\
\hline $\begin{array}{l}\text { Worcester Polytechnic Institute }{ }^{[25]} \\
\text { Worcester, MA }\end{array}$ & College of Engineering & 4 & 144 & Semester \\
\hline $\begin{array}{l}\text { University of Wyoming }{ }^{[26]} \\
\text { Laramie, WY }\end{array}$ & $\begin{array}{l}\text { College of Engineering and } \\
\text { Applied Science }\end{array}$ & 4 & 128 & Semester \\
\hline & & $\dot{*}$ & \multicolumn{2}{|c|}{$\begin{array}{l}\text { Indicates combined or Integrated } 5 \\
\text { year Bachelors/Masters degree }\end{array}$} \\
\hline
\end{tabular}

Table 1: Department and degree length for ABET Accredited AE Programs 
number of credit hours shown in parenthesis based on a ratio of $2 / 3$. There are 15 programs that have four year curriculums, and the average credit hours for graduation at these are 129, with a low of 126 and a high of 132. The program at Worcester Polytechnic Institute also has a four year curriculum however it uses a unit system, which equates to approximately 144 credit hours. For the five year Architectural Engineering programs the average credit hours are 163 with a low of 157 and a high of 170, though the merits of using these numbers for comparison may be questionable when considering that three of the programs offer bachelor degrees and the other two offer combined/integrated bachelors/masters degrees.

One trend that became apparent during this research was the reduction in the number of credit hours, and thus the time and cost involved, in graduating from AE programs. Of the 17 programs in existence in 2007, five have the same number of credit hours today however seven programs decreased the number of required credit hours by an average of 3.7 hours. Only two of the programs increased the number of credit hours required during this time with both programs increasing the required hours by 2 . One program restructured their program into a five year Master degree program, and the remaining two programs, KU and KSU, have reduced their programs to four year from the previous five year curriculums. This change from a five year to a four year curriculum is worth noting as many programs are under pressure from multiple sources (such as administration and industry) to reduce the total number of credit hours required for graduation.

Another aspect of this study included the curriculum focus of each program. With the four curriculum areas that must be included in ABET accredited AE programs, along with the requirement of one design, one application, and two comprehension areas, there are many variations that can occur between the programs. This study took a look at the focus of each program in terms of degree options and Table 2 shows the results. It was found that many of the programs did not have a clearly defined curriculum dedicated to one more of the four focus areas included in ABET requirements: building structures, building mechanical systems, building electrical systems, and construction/construction management, that resulted in a degree option available within a program. More than half of the AE programs do not offer degree options as part of their curriculum offerings, however one must keep in mind that degree options are not a requirement of ABET. Of the ten programs that offer degree options, one program has one degree option, three programs have two degree options, five programs have three degree options, and one program (Penn State) offers degree options in all four areas of focus. In looking at a breakdown of the options offered by these programs, all ten offer an option in building structures, three programs offer an option in construction/construction management, seven offer an option in building mechanical systems, four offer an option in building electrical systems, and two programs offer degree options in combined building mechanical and electrical systems.

This study considered a degree option within a program as one that was either clearly identified in the program's online information, or that in reviewing the programs curricular requirements it became clear that the program had a defined focus for the degree from that institution. As an example, the current AE program at California Polytechnic State University does not identify a specific focus though in a review of the curriculum it becomes apparent that the program has a predominant focus in building structures, and thus it was included as offering a degree option is building structures. 


\begin{tabular}{|c|c|c|c|c|c|c|c|c|c|c|c|}
\hline \multirow[b]{2}{*}{$\begin{array}{l}\text { ABET Accredited } \\
\text { Architectural Engineering } \\
\text { Programs }\end{array}$} & \multicolumn{5}{|c|}{ AE Degree Options } & \multicolumn{6}{|c|}{ Degrees Awarded } \\
\hline & 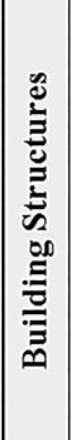 & 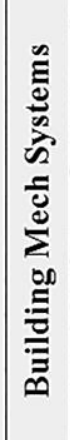 & 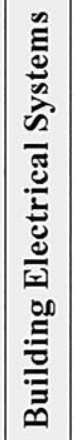 & 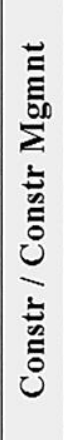 & 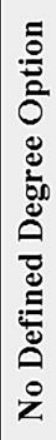 & $\begin{array}{l}\dot{0} \\
\dot{0} \\
\dot{\sigma} \\
\dot{\sigma} \\
\sigma\end{array}$ & 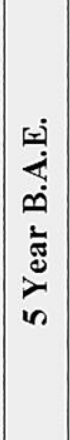 & 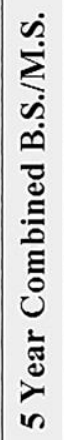 & 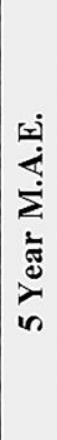 & 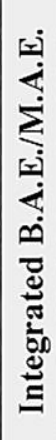 & 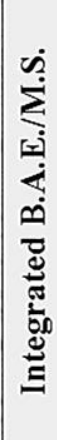 \\
\hline $\begin{array}{l}\text { California Polytechnic State University } \\
\text { San Luis Obispo, CA }\end{array}$ & $X$ & & & & & 0 & & & & & \\
\hline $\begin{array}{l}\text { University of Colorado at Boulder } \\
\text { Boulder, CO }\end{array}$ & & & & & $X$ & 0 & & & & & \\
\hline $\begin{array}{l}\text { University of Detroit Mercy } \\
\text { Detroit, MI }\end{array}$ & $X$ & \multicolumn{2}{|c|}{$X$} & $X$ & & & - & & & & \\
\hline $\begin{array}{l}\text { Drexel University } \\
\text { Philadelphia, PA }\end{array}$ & $X$ & $X$ & & & & - & & & & & \\
\hline $\begin{array}{l}\text { Illinois Institute of Technology } \\
\text { Chicago, IL }\end{array}$ & & & & & $X$ & - & & & & & \\
\hline $\begin{array}{l}\text { University of Kansas } \\
\text { Lawrence, KS }\end{array}$ & & & & & $X$ & 0 & & & & & \\
\hline $\begin{array}{l}\text { Kansas State University } \\
\text { Manhattan, KS }\end{array}$ & $X^{*}$ & $X^{*}$ & $X^{*}$ & & $X$ & $\bullet$ & & $\bullet$ & & & \\
\hline $\begin{array}{l}\text { Lawrence Technological University } \\
\text { Southfield, MI }\end{array}$ & & & & & $X$ & & & 0 & & & \\
\hline $\begin{array}{l}\text { University of Miami } \\
\text { Coral Gables, FL }\end{array}$ & & & & & $X$ & • & & & & & \\
\hline $\begin{array}{l}\text { Milwaukee School of Engineering } \\
\text { Milwaukee, WI }\end{array}$ & $X$ & $X$ & $X$ & & & - & & & & & \\
\hline $\begin{array}{l}\text { Missouri University of Science and Technology } \\
\text { Rolla, MO }\end{array}$ & & & & & $X$ & $\bullet$ & & & & & \\
\hline $\begin{array}{l}\text { University of Nebraska - Lincoln } \\
\text { Lincoln, NE }\end{array}$ & $X$ & $X$ & $X$ & & & & & & - & & \\
\hline $\begin{array}{l}\text { North Carolina A\&T State University } \\
\text { Greensboro, NC }\end{array}$ & & & & & $X$ & - & & & & & \\
\hline $\begin{array}{l}\text { University of Oklahoma } \\
\text { Norman, OK }\end{array}$ & & & & & $X$ & $\bullet$ & & & & & \\
\hline $\begin{array}{l}\text { Oklahoma State University } \\
\text { Stillwater, OK }\end{array}$ & $X$ & & $X$ & $X$ & & & 0 & & & & \\
\hline $\begin{array}{l}\text { Pennsylvania State University } \\
\text { University Park, PA }\end{array}$ & $X$ & $X$ & $X$ & $X$ & & & 0 & & & 0 & $\bullet$ \\
\hline $\begin{array}{l}\text { Tennessee State University } \\
\text { Nashville, TN }\end{array}$ & & & & & $X$ & - & & & & & \\
\hline $\begin{array}{l}\text { Texas A\&M University - Kingsville } \\
\text { Kingsville, TX }\end{array}$ & & & & & $X$ & - & & & & & \\
\hline $\begin{array}{l}\text { University of Texas at Austin } \\
\text { Austin, TX }\end{array}$ & & & & & $X$ & - & & & & & \\
\hline $\begin{array}{l}\text { Worcester Polytechnic Institute } \\
\text { Worcester, MA }\end{array}$ & $X$ & $X$ & & & & $\bullet$ & & & & & \\
\hline $\begin{array}{l}\text { University of Wyoming } \\
\text { Laramie. WY }\end{array}$ & $X$ & $X$ & & & & - & & & & & \\
\hline & & & & & & & & & & & \\
\hline
\end{tabular}

Table 2: Degrees awarded and options for ABET accredited AE programs 
In reviewing the number of credit hours one should also consider what type of degree is offered by the programs. Table 2 lists the types of accredited degree awarded, with sixteen of the programs offering four-year Bachelor degrees. One of these sixteen programs offers the choice between a four-year B.S. degree and also a five-year combined B.S./M.S. degree. Beyond those 16 programs, two AE programs offer a five-year Bachelor degree, and another program offers the choice between a five-year Bachelor degree, an integrated B.A.E./M.A.E. degree, or an integrated B.A.E./M.S. degree. Finally, one of the programs offers a five-year combined B.S./M.S. degree, and another program offers a five-year ABET accredited M.A.E. degree.

A final part of the study involved a review of graduation rates for each program. The statistics shown in Table 3 for this portion of the study were taken primarily from the American Society for Engineering Educators interactive site [27]. This website gives access to data on a variety of issues for individual programs, with the information submitted to ASEE by each institution. In one case information was not found for an individual program on the website and is indicated as such in Table 3. For some programs it should be noted that the data available on the ASEE website did not agree with graduation rates available on an individual program's website. This may be in part due to improper data being submitted to ASEE by an institution, as was encountered at this author's institution, thus the data in Table 3 may not coincide with graduation data available on an individual program's website. For programs where information could not be found on either the ASEE or program's website, the table indicates NA (Not Available) for those graduation rates.

In a review of the graduation rates the programs were grouped based on the average number of graduates over the past five years. Five of the programs had upper range graduation rates (40 or more on average) with the highest being Penn State University averaging 93 graduates per year. Seven of the programs had medium range graduation rates (20 or more on average), and nine of the programs had lower range graduation rates (less than 20 on average). Overall the graduation rates have remained relatively constant over the past seven years when including estimates for missing data, though over the past decade the graduation rates have declined. With the current positive state of the economy and construction industry there continues to be a high demand for engineers in this area and it would be worth further study as to why the number of AE graduates has declined over the past decade.

\section{How this information can help Architectural Engineering programs}

Architectural Engineering programs are in competition with other branches of engineering, such as civil, mechanical, electrical, and construction engineering. The small number of AE programs within the U.S. can be used to an advantage by forging a close knit group of educators, researchers, and students that can have a great impact on our profession. To perform this study without disseminating the findings to others in the field of education would be a disservice, thus it is the intent to find a way for those interested to view the information researched. One goal is to establish a website resource where this information is available to all, and initial discussions have begun to work through the logistics of establishing a database of information that could be available on the Architectural Engineering Institute (AEI) division of the American Society of Civil Engineers (ASCE) website. Once established it should become the responsibility of each 


\begin{tabular}{|c|c|c|c|c|c|c|c|}
\hline $\begin{array}{c}\text { Graduation Statistics for } \\
\text { ABET Accredited AE } \\
\text { Programs }\end{array}$ & $\overline{\bar{N}}$ & 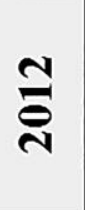 & 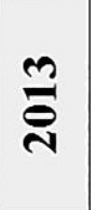 & $\underset{\ominus}{ \pm}$ & $\frac{n}{\tilde{N}}$ & $\frac{0}{\tilde{N}}$ & 흉 \\
\hline $\begin{array}{l}\text { California Polytechnic State University } \\
\text { San Luis Obispo, CA }\end{array}$ & 54 & 62 & 33 & 46 & 43 & 48 & 56 \\
\hline $\begin{array}{l}\text { University of Colorado at Boulder } \\
\text { Boulder, CO }\end{array}$ & 42 & 58 & 43 & 34 & 40 & 29 & 35 \\
\hline $\begin{array}{l}\text { University of Detroit Mercy } \\
\text { Detroit, MI }\end{array}$ & --- & --- & --- & --- & --- & 3 & 1 \\
\hline $\begin{array}{l}\text { Drexel University } \\
\text { Philadelphia, PA }\end{array}$ & 46 & 48 & 45 & 43 & 51 & 57 & 44 \\
\hline $\begin{array}{l}\text { Illinois Institute of Technology } \\
\text { Chicago, IL }\end{array}$ & 20 & 27 & 16 & 21 & 16 & 13 & 10 \\
\hline $\begin{array}{l}\text { University of Kansas } \\
\text { Lawrence, KS }\end{array}$ & 26 & 26 & 28 & 30 & 38 & 26 & 25 \\
\hline $\begin{array}{l}\text { Kansas State University } \\
\text { Manhattan, KS }\end{array}$ & 47 & 47 & 55 & 61 & 47 & 39 & 39 \\
\hline $\begin{array}{l}\text { Lawrence Technological University } \\
\text { Southfield, MI }\end{array}$ & --- & --- & --- & --- & --- & --- & 11 \\
\hline $\begin{array}{l}\text { University of Miami } \\
\text { Coral Gables, FL }\end{array}$ & 15 & 13 & 7 & 9 & 11 & 11 & 16 \\
\hline $\begin{array}{l}\text { Milwaukee School of Engineering } \\
\text { Milwaukee, WI }\end{array}$ & 88 & 68 & 67 & 44 & 31 & 31 & 38 \\
\hline $\begin{array}{l}\text { Missouri University of Science and Technology } \\
\text { Rolla, MO }\end{array}$ & 48 & 48 & 54 & 44 & 39 & 33 & 26 \\
\hline $\begin{array}{l}\text { University of Nebraska - Lincoln } \\
\text { Lincoln, NE }\end{array}$ & 22 & 27 & 22 & 21 & 26 & 27 & 19 \\
\hline $\begin{array}{l}\text { North Carolina A\&T State University } \\
\text { Greensboro, NC }\end{array}$ & 24 & 25 & 20 & $\mathbf{N A}$ & $\mathbf{N A}$ & $\mathbf{N A}$ & NA \\
\hline $\begin{array}{l}\text { University of Oklahoma } \\
\text { Norman, OK }\end{array}$ & 8 & 11 & 11 & 10 & 5 & 11 & 11 \\
\hline $\begin{array}{l}\text { Oklahoma State University } \\
\text { Stillwater, OK }\end{array}$ & 11 & 8 & 7 & 11 & 12 & 9 & 15 \\
\hline $\begin{array}{l}\text { Pennsylvania State University } \\
\text { University Park, PA }\end{array}$ & 103 & 93 & 101 & 102 & 82 & 96 & 84 \\
\hline $\begin{array}{l}\text { Tennessee State University* } \\
\text { Nashville, TN }\end{array}$ & 4 & 5 & 2 & 9 & 5 & $\mathbf{N A}$ & NA \\
\hline $\begin{array}{l}\text { Texas A\&M University - Kingsville } \\
\text { Kingsville, TX }\end{array}$ & 13 & 8 & 18 & 12 & 2 & 12 & 18 \\
\hline $\begin{array}{l}\text { University of Texas at Austin } \\
\text { Austin, TX }\end{array}$ & 30 & 56 & 24 & 35 & 42 & 44 & 46 \\
\hline $\begin{array}{l}\text { Worcester Polytechnic Institute } \\
\text { Worcester, MA }\end{array}$ & --- & --- & --- & 6 & 3 & 16 & 11 \\
\hline $\begin{array}{l}\text { University of Wyoming } \\
\text { Laramie, WY }\end{array}$ & 17 & 17 & 17 & 17 & 17 & 27 & 20 \\
\hline Summation of ABET accredited degrees awarded & 618 & 647 & 570 & 555 & 510 & 532 & 525 \\
\hline
\end{tabular}

Table 3: Graduation statistics for ABET accredited AE programs 
AE program to keep their information current. The goal is to help understand the focus and strengths of each program which can help facilitate collaboration between them, and to provide the public a resource to use for a better understanding of Architectural Engineering.

\section{Further work on this topic}

Once this initial information is utilized to establish a database, additional information can then be added to expand the understanding of the AE programs. As an example, the 2007 study on Architectural Engineering programs included information on the curriculums of each program. This information should be updated and added to the database so that it is useful in the evaluation of each program. Also a study on diversity can be included to gain insight into the breakdown of the students in each program. An additional focus of further research should also include the ABET accredited AE programs around the world. Though small in number, with only 3 ABET accredited AE programs currently in existence outside the U.S., research on these programs would add to the database and could give insight into collaborative opportunities with these programs. Additionally, a new AE program at the University of Cincinnati is on the verge of ABET accreditation and information on this program will be added to the database in the future. Beyond looking at ABET accredited programs, the database could expand to include any program looking to become ABET accredited, and could even be opened to non-accredited Architectural Engineering programs.

\section{Conclusion}

It has been 10 years since a study of the ABET accredited Architectural Engineering programs in the U.S. has occurred and in that time that addition of new programs along with changes to existing programs have occurred. This study of the current offerings in the field of Architectural Engineering education will be used to establish a database for use by the general public. Additionally this information will allow AE programs to better understand their strengths, weaknesses, and opportunities going forward. The use of this information can be used in a number of ways, including the evaluation of an existing program to determine if changes made could increase the opportunities for the University, the students, and the profession. Such was the result of parts of this study for Oklahoma State University as it was used to help arrive at a decision to offer new AE degree options to their curriculum that were recently introduced[5]. Ultimately the information from this study can be used by the ABET accredited Architectural Engineering programs in discussions on how they can work together in the promotion and betterment of the field of Architectural Engineering education.

\section{Disclaimer}

The information included in this paper was primarily gathered online from each program and is generally available to the public. This information was at times subject to interpretation by the author based on the available information found on each program. It was not the author's intent to either promote or discredit any of the Architectural Engineering programs by the information included in this paper. Any discrepancies found and brought to the attention of the author will gladly be corrected when the research is made available to the public through an online resource such as the ASCE/AEI website. 


\section{References}

[1] “Criteria for Accrediting Engineering Programs, 2016 - 2017,” ABET Criteria for Accrediting Engineering Programs. [Online]. Available: http://www.abet.org/accreditation/accreditation-criteria/criteria-foraccrediting-engineering-programs-2016-2017/ - program [Accessed: 10/15/17].

[2] B. Yoder, "Engineering By the Numbers", American Society for Engineering Educators Engineering College Profiles \& Statistics Book, 2016. [Online]. Available: https://www.asee.org/documents/papers-andpublications/publications/college-profiles/16Profile-Front-Section.pdf [Accessed 1/23/18].

[3] A. Estes, and H. Estrada, "Architectural Engineering Programs: Finding Common Ground" in 2007American Society for Engineering Education Annual Conference \&Exposition Proceedings, ASEE 2007, Honolulu, HI, USA, June 24-27, 2007, [AC 2007-870].

[4] J. Mitchell, "Defining Architectural Engineering Design" in 2009American Society for Engineering Education Annual Conference \&Exposition Proceedings, ASEE 2009, Austin, TX, USA, June 14-17, 2009, [AC 2009-448].

[5] J. Phillips, "Updating the Curriculum in an AE Program to Include New Degree Options" in AEI 2017 Resilience of the Integrated Building, AEI 2017, Oklahoma City, OK, USA, April 11-13, 2017.

[6] College of Architecture and Environmental Design website, California Polytechnic State University, San Luis Obispo, CA. [Online]. Available: http://arce.calpoly.edu/ [Accessed 1/24/18].

[7] College of Engineering \& Applied Science website, University of Colorado at Boulder, Boulder, CO. [Online]. Available: http://www.colorado.edu/engineering/academics/degree-programs/architecturalengineering [Accessed 1/24/18].

[8] College of Engineering \& Science website, University of Detroit Mercy, Detroit, MI. [Online]. Available: http://eng-sci.udmercy.edu/academics/engineering/architectural/undergrad.php [Accessed 1/24/18].

[9] College of Engineering website, Drexel University, Philadelphia, PA. [Online]. Available: https://wwwfuture.drexel.edu//cae/academics/bs-architectural-engineering/ [Accessed 1/24/18].

[10] Armour College of Engineering website, Illinois Institute of Technology, Chicago, IL. [Online]. Available: https://engineering.iit.edu/programs/undergraduate/bachelor-science-architectural-engineering [Accessed $1 / 25 / 18]$.

[11] College of Engineering website, University of Kansas, Lawrence, KS. [Online]. Available: https://ceae.ku.edu/ [Accessed 1/25/18].

[12] Department of Architectural Engineering \& Construction Science website, Kansas State University, Manhattan, KS. [Online]. Available: http://www.are-cns.ksu.edu/ [Accessed 1/25/18].

[13] College of Engineering website, Lawrence Technological University, Southfield, MI. [Online]. Available: https://www.ltu.edu/engineering/architectural/architectural-engineering-undergrad-grad.asp [Accessed $1 / 25 / 18]$.

[14] College of Engineering website, University of Miami, Coral Gables, FL. [Online]. Available: http://www.coe.miami.edu/departments/cae-engineering/undergraduate/ [Accessed 1/26/18].

[15] Architectural Engineering website, Milwaukee School of Engineering, Milwaukee, WI. [Online]. Available: http://www.msoe.edu/academics/engineering-undergraduate-programs/architectural-engineering-overview/ [Accessed 1/26/18].

[16] Civil, Architectural and Environmental Engineering website, Missouri University of Science and Technology, Rolla, MO. [Online]. Available: http://care.mst.edu/architecturalengineering/undergraduate/ [Accessed $1 / 26 / 18]$.

[17] Durham School of Architectural Engineering \& Construction website, University of Nebraska - Lincoln, Lincoln, NE. [Online]. Available: http://engineering.unl.edu/durhamschool/architectural-engineering/ [Accessed 1/26/18].

[18] Department of Civil, Architectural and Environmental Engineering website, North Carolina Agricultural and Technical State University, Greensboro, NC. [Online]. Available: http://www.ncat.edu/coe/departments/caee/index.html [Accessed 1/27/18].

[19] Gallogly College of Engineering website, University of Oklahoma, Norman, OK. [Online]. Available: http://www.ou.edu/content/coe/cees/undergrad_programs/arch engineering.html [Accessed 1/27/18].

[20] School of Architecture website, Oklahoma State University, Stillwater, OK. [Online]. Available: https://archceat.okstate.edu/architectural-engineering-program [Accessed 19/15/17].

[21] College of Engineering website, Pennsylvania State University, University Park, PA. [Online]. Available: http://www.ae.psu.edu/index.aspx [Accessed 1/27/18]. 
[22] College of Engineering website, Tennessee State University, Nashville, TN. [Online]. Available: http://www.tnstate.edu/ae/Degrees.aspx [Accessed 1/27/18].

[23] Frank H. Dotterweich College of Engineering website, Texas A \& M University - Kingsville, Kingsville, TX. [Online]. Available: http://www.tamuk.edu/engineering/departments/caen/degrees/aeen.html [Accessed $1 / 28 / 18]$.

[24] Cockrell School of Engineering website, University of Texas at Austin, Austin, TX. [Online]. Available: http://www.caee.utexas.edu/architectural [Accessed 1/28/18].

[25] Department of Civil \& Environmental Engineering website, Worcester Polytechnic Institute, Worcester, MA. [Online]. Available: https://www.wpi.edu/academics/study/architectural-engineering-bs [Accessed 1/28/18].

[26] College of Engineering and Applied Science website, University of Wyoming, Laramie, WY. [Online]. Available: http://www.uwyo.edu/civil// [Accessed 1/28/18].

[27] American Society for Engineering Educators website. [Online]. Available: http://profiles.asee.org/ [Accessed 12/1/17]. 